This new Section of Epidemiology and Psychiatric Sciences is dedicated to all forms of creative production born of an intimate and individual urge, often secretive, unbound from the conventional art system rules. Through short descriptions of the Outsider art work of prominent artists and new protagonists often hosted in community mental health services, this section intends to investigate the latest developments of the contemporary art scene, where the distances between the edge and the centre are becoming more and more vague.

Carole Tansella, Section Editor

\title{
The seminal work of Carlo Zinelli
}

\section{Tansella}

Department of Time, Space, Image, Society. University of Verona, Verona, Italy.

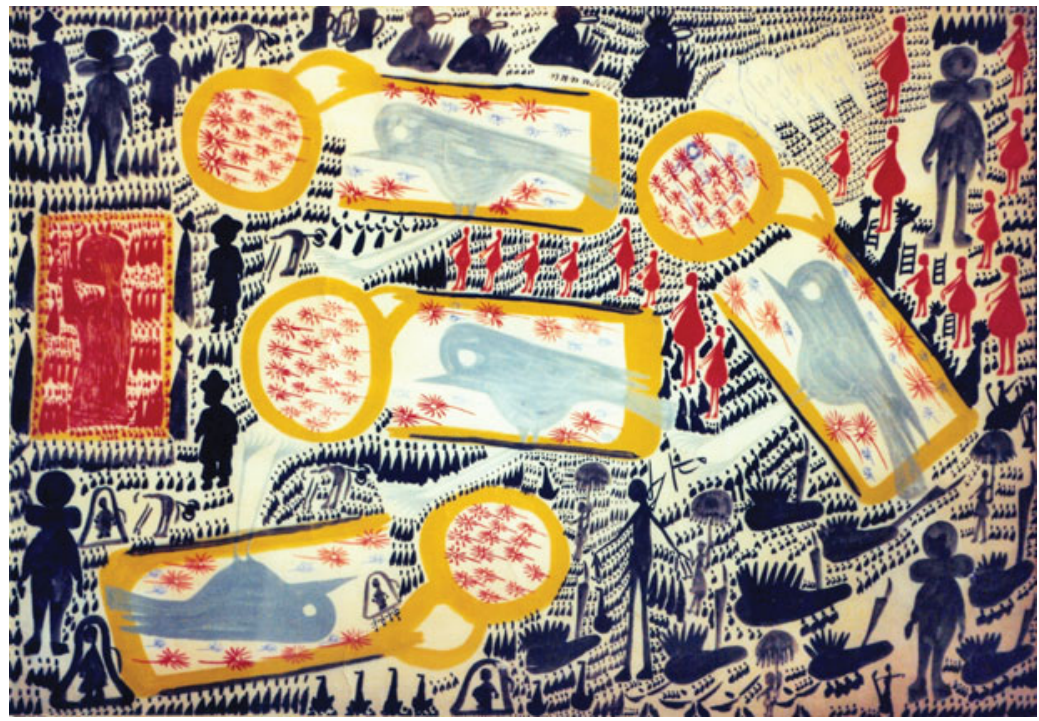

Carlo Zinelli: Quattro uccelli grigi entro forme gialle, tempera su carta, 1962,35 ×50 cm, Collection: A. Fasoli Courtesy of Fondazione Carlo Zinelli, S. Giovanni Lupatoto (Verona). Full colour version available as online supplementary material. http://dx.doi.org/10.1017/S2045796012000728

Carlo Zinelli (1916-1974) was born in San Giovanni Lupatoto, Verona. He was only 2 years old when his mother died. Seven years later, his father, a carpenter,

Address for correspondence: Dr Carole Tansella, Department of Time, Space, Image, Society. University of Verona, Via San Francesco 22, 37129 Verona, Italy.

(Email: carole.tansella@yahoo.it; carole.tansella@univr.it) sent him to work in the fields. In 1934, he moved to Verona, where he worked in the city slaughterhouse. At this time, he began to paint, and his first completely realized work was the decoration of all the walls of his kitchen at home. During the Spanish Civil War, he was conscripted into the Alpine corps and, in 1939, he embarked in Naples for Spain. After a few months he was home again as the result of 'special permission.' 
It was during this period that he began to show the first signs of mental disturbance.

Even though he was frequently hospitalized, Zinelli continued to work and to cultivate his enthusiasm for music and dancing. When he was 31, he was committed to the San Giacomo alla Tomba psychiatric hospital in Verona. After about 10 years he began to scratch graffiti on the walls of the hospital. In 1957, the medical personnel recognized his need for expression, and they involved him in creative activity in the painting studio that had been set up by three men: the British sculptor Michael Noble, psychiatrist Dr Mario Marini and the hospital director, Professor Cherubino Trabucchi.

This was a decisive moment for Zinelli, not just from an artistic point of view, but in terms of the way in which it shaped his entire existence in the mental hospital. He devoted at least $8 \mathrm{~h}$ a day to painting. Zinelli produced over 2000 works of art. His graphic language is characterized by the repetition of certain constant elements and by his inquiries into such themes as nature, Alpinism, and the relationship between men and women. He almost always painted on both sides of the paper and often rounded off his works with written elements.

Zinelli's artistic output followed a coherent development in which each work reconfirms the genius and volcanic imagination of its painter. As only great artists are able to do, Zinelli too breaks down boundaries, reveals principles, and schemes are shown for what they are: preconceived. The distinctions between traditional art and outsider or art brut (arte irregolare) lose their meaning in the face of the strength of his continuous and original artistic research (Tansella, 2012). Zinelli took part in numerous exhibitions in Italy and abroad and was the first Italian painter to be part of Jean Dubuffet's Collection d'Art Brut in Lausanne. Today his name is numbered among the great protagonists of art history and his works are exhibited throughout the world.

\section{Supplementary materials and methods}

The Supplementary material referred to in this article can be found at http://dx.doi.org/10.1017/ S2045796012000728.

\section{Reference}

Tansella C (2012). Authentic visions. In Autentiche Visioni. Verona e l'Arte Irregolare da Carlo Zinelli a Oggi, Exhibition Catalogue, 9 November 2012-27 January 2013, Grafiche Aurora, Verona. 